\title{
Reproductive Performances of Indigenous Ewes in Bangladesh
}

\author{
Begum Fatema Zohara ${ }^{1}$, Azizunnesa ${ }^{2}$, Md. Faruk Islam ${ }^{1}$, Md. Golam Shahi \\ Alam $^{3}$ and Farida Yeasmin Bari ${ }^{3}$ \\ ${ }^{1}$ Department of Medicine, Surgery and Obstetrics, Hajee Mohammad Danesh Science and Technology \\ University, Dinajpur, Bangladesh) \\ ${ }^{2}$ Department of Medicine and Surgery, Chittagong Veterinary and animal Sciences University, \\ Chittagong, Bangladesh) \\ ${ }^{3}$ (Department of Surgery and Obstetrics, Bangladesh Agricultural University, Mymensingh, Bangladesh)
}

\begin{abstract}
The ewes were randomly divided into controlled and supplemented group to determine the reproductive performances of indigenous ewes in Bangladesh. Ewe lambs on supplemented group was growing faster and reached puberty at significantly $(p<0.05)$ younger age $(6.22 \pm 1.31$ months). There was a significant $(p<0.05)$ interaction of supplemented feed and average daily gain during puberty. The oestrus cycle length and duration of estrus was not significantly $(p>0.05)$ different between the two groups. The stage of the estrous cycle was determined by observing exfoliated vaginal cells in both the groups. Average progesterone concentration was significantly different $(p<0.01)$ among days of the oestrous cycle. Progesterone concentration was $<1.0 \mathrm{ng} / \mathrm{ml}$ on day of estrus, rose steadily to peak on days 10 and followed by a rapid decline on day 15 in both group. The nutritional supplement did not improve sexual behaviors. The pregnancy rates were 83.33 and $100 \%$ in controlled and supplemented groups. The gestation length varied from 141 to 145 days. The post partum onset of estrus was significantly shorter in supplemented group than controlled group $(p<0.05)$. The lambing rates, litter size and lamb survival rate were 75 and $100 \%, 1.22 \pm 0.44$ and $.1 .58 \pm 0.67$ and 91.67 and 100\%, in controlled and supplemented group, respectively. Mean birth weights of lambs were $1.00 \pm 0.30$ and $1.33 \pm 0.25 \mathrm{~kg}$ in controlled and supplemented group, respectively. The pre-weaning average daily gain of lambs were significantly different $(p<0.01)$ between two groups. The present study indicates the influence of nutrition on reproductive performances of ewes that may increase and improve the sheep production.
\end{abstract}

Keywords: reproductive performances, supplementation, indigenous ewes.

\section{Introduction}

There are about 3.12 million sheep in Bangladesh [1]. Bangladesh is a sub-tropical country, favorable for sheep breeding, as they can be maintained under rural conditions because of their ability to adapt to harsh environment, poor management and feeding practices. However, farmer who keeps a significant number of sheep that is not ideally productive due to poor genetic merit [2], [3], poor nutrition and management [4] seasonal fluctuations in feed resources and diseases [5]. They are slow in body growth and small in body size. Therefore rearing of sheep is unable to ensure food security and a better living standard to the sheep farmers at the present time.

In our country, sheep and goat are mainly kept by the poor farmers and distressed women in extensive system under ranged condition without any supplementation. Under nutrition results in the loss of body weight and body condition, delays the onset of puberty, increases the post-partum onset of estrus, interferes with normal ovarian cyclicity by decreasing gonadotropin secretion and increases infertility [6], [7], [8]. Nutrition during gestation not only affects maternal body weight gain, body condition, and reproductive performance [9]; [10], but also affects prenatal and postnatal offspring growth and development [11], [12].

Previous studies [13], [14] have reflected the importance of concentrate supplementation on growth and productivity of goats and sheep. The interaction between nutrition and reproduction has long been known to have important implications for the reproductive performance [15].

Reproductive performances are prerequisite and important issue for any successful breeding programme and determinants of productivity of livestock farming systems. There has been no detailed study on reproductive performances of indigenous ewes in Bangladesh. Furthermore, the endocrine regulation of oestrus cycle never been studied. Therefore, the present study was conducted to determine the reproductive performances of indigenous ewes in Bangladesh. 


\subsection{Study area}

\section{Material and Methods}

The study was carried out at the Department of Surgery and Obstetrics, Bangladesh Agricultural University, Mymensingh. The research units are located on N 24.73 and E 90.44 latitude and longitude, respectively and elevated $9 \mathrm{~m}$ above sea level. The area receives on average $174 \mathrm{~mm}$ of rainfall. Mean annual minimum and maximum temperatures experienced at the site are 16.46 and $29.13^{\circ} \mathrm{C}$, respectively.

2.2 Study design

The study was conducted between January to December, 2011. A total of 24 clinically healthy indigenous ewes of 2- 3 months old and $6-8 \mathrm{~kg}$ body weight were selected from the local market. After preliminary acclimatization, all the animals were dewarmed and vaccinated for rabies and tetanus. Two grown up rams were vasectomized in the laboratory to be used as teasure. Indigenous experienced rams were used for natural service. The ewes randomly divided in to either controlled or supplemented group. The controlled group was maintained on natural grazing with traditional feeding practice used by the farmer and the supplemented group was maintained with supplemented feeding ration along with natural grazing. All ewes in the supplemented group received the supplemental diet (composed of concentrate mixture 25\% Crushed Maize, $50 \%$ Wheat Bran, 20\% Soybean meal, 1\% Fish meal, 2\% DCP Powder, 1.5\% salt and 0.5\% vitamin- mineral premix) for a minimum of 120 days prior to collecting data. The supplementation was at the rate of $300 \mathrm{~g} / \mathrm{head}$ /day. Water was supplied ad labium. Proximate composition analysis of the supplements were carried out to measure the content of Crude Protein, Crude fiber, Ash, Lipid, Carbohydrate and Moisture according to methodologies recommended by AOAC [16]. The compositions of diets are presented in Table 1.

\subsection{Measurement of growth rate, age and body weight at puberty of ewes}

Body weight was recorded weekly by a balance scale. Daily weight gain was calculated by dividing the total weight gain by the total days of feeding period. Age at puberty was recorded by the onset of first behavioral estrus.

2.4 Measurement of Estrus cycle length, duration and stages of ewes

Estrous detection in ewes was carried out twice a day for $1 \mathrm{~h}$ period of observation using vasectomized ram. Estrus duration was defined as the time interval between the onset of estrus and when a ewe no longer stood to be mounted [33] while estrous cycle length was defined as the number of days between the onsets of two consecutive estrous periods [17]. The stages of the cycle were determined by vaginal cytology [18].

Ovulation response and cyclical stages was further confirmed by the measurement of serum progesterone concentration. Blood sample $(5 \mathrm{ml})$ was collected from each ewe of both groups on every $5^{\text {th }}$ day for Day 16 of the cycle. Serum was recovered by centrifugation $(15$ minutes at $3000 \mathrm{rpm})$ and stored at $-20^{\circ} \mathrm{C}$ until assayed for serum progesterone concentrations using commercially available sheep progesterone (PROG) ELISA kit (Cusabio Biotech Co., Ltd.). Each ewe was considered to have ovulated when progesterone concentration was $\geq 0.5 \mathrm{ng} / \mathrm{ml}[19]$.

\subsection{Detection of estrus and natural service}

Ewes and vasectomized rams were kept together in a paddock for one hour twice a day for observing the behavioral signs. The behaviors of animals were noted on individual sheets prepared for each ewe. Each ewe was considered to be in estrus when she was directly observed to accept a mount from the ram. The ewes were hand mated/ NS twice at $12 \mathrm{hrs}$ interval.

\subsection{Pregnancy, gestation length and post partum onset of oestrus}

Pregnancy was determined by transabdomial ultrasonography, using B-mode diagnostic ultrasound scanner (DRAMIŃSKI, Poland) at 50 days of natural service. Gestation length was counted from the day of service to the day of onset of labor. Post partum onset of estrus was determined by the first observed estrus after parturition and by observing the vaginal cytology. Pregnancy rate, Lambing and fertility rate, litter size was calculated by the following formula [20].

Pregnancy rate $(\%)=$ (number of ewes pregnant / ewes present to rams) $\mathrm{x} 100$.

Lambing rate $(\%)=$ (number of ewes lambing /number of ewes mated) $\times 100$.

Lamb survival rate $(\%)=$ Number of offspring weaned/ Number of offspring produced $\mathrm{x} 100$

Litter size $($ prolificacy) $=$ Number of lambs / number of ewes lambing

\subsection{Lamb birth weight, weaning weight and pre-weaning average daily weight gain of lamb}

Within 24 hours of the new born, date of birth, birth weight, type of birth, sex of lamb was taken. The numbers of lambs born per ewe were recorded daily during lambing. Weaning weight was recorded on $60^{\text {th }}$ day by the following formula:

Pre-weaning Average Daily Gain = (weaning weight - birth weight) / weaning age 


\subsection{Data analysis}

Data analysis was carried out to evaluate the differences in results between supplemented and control animals using students "t" test. Sexual behaviors were compared by Chi-Square test. Pregnancy, lambing and lamb survival rate was expressed in percentage. The mean progesterone concentrations between groups were analyzed by ANOVA-repeated measures (GLM procedure of (SPSS.), Version 17.0). All significant differences were set at $\mathrm{P}<0.05$.

\subsection{Age, weight at puberty and daily weight gain}

\section{Results}

The age, weight at puberty and daily weight gain in indigenous ewes is shown in the Table 2 . The age at puberty varied from 5-11 months. Ewe lambs on supplemented group reached puberty at significantly $(\mathrm{p}<0.05)$ younger age $(6.22 \pm 1.31$ months $)$ than controlled group $(8.43 \pm 1.15$ months). Similarly, the ewes in supplemented group was growing faster than ewes in controlled group $(\mathrm{p}<0.01)(10.38 \pm 0.39 \mathrm{~kg}$ vs. $9.1583 \pm 1.06$ $\mathrm{kg})$. There was a significant $(\mathrm{p}<0.05)$ interaction of supplemented feed and average daily gain during puberty.

\subsection{The estrus cycle length, stages and duration of estrus and Progesterone concentration}

The estrus cycle length and duration of estrus in indigenous ewes is placed in Table 2 and stages placed in Fig. 1. The estrus cycle length varied from 14 to 20 . The estrus cycle length was not significantly ( $>0.05)$ different between two groups (15.81 \pm 0.38 vs.16.06 \pm 0.35 days). Duration of estrus in the present study varied from 24 to 36 hrs. There was no significant difference ( $p>0.05)$ in duration of estrus in indigenous ewes between the supplemented and controlled group. The observed duration of estrus was $32.75 \pm 3.19$ and $33.17 \pm 3.01 \mathrm{hrs}$, respectively.

The stage of the estrous cycle was determined by observing the exfoliated vaginal cells in both the groups (Fig. 1 and 2). In oestrus, large number of anucleated cornified cells were present (60 to 100\%) which occurred in clusters (Fig. 2-B). The day of estrus was designated as day 0 of the cycle (Fig. 1). Metoestrus was predominant with leukocytes in addition with cornified and nucleated cells (Fig. 2-C) and lasted for about 3 days. Dioestrus was dominated by leukocytes (Fig. 2-D). In the present study in indigenous ewes it extended from about day 4 through day 13,14,15,16 or 17. Proestrus was determined by the presence of predominantly large number of large round nucleated epithelial cells (Fig. 2-A), these cells may appear in clusters or individually. Occasionally, some cornified cells were appeared within this period. The changes in serum progesterone levels of both groups showed no statistically differences to each other (Table 3). The microscopic changes during the stages matched with hormonal profiles. Average progesterone concentration was significantly different $(\mathrm{p}<0.01)$ among days of the oestrous cycle. Progesterone concentration was $<1.0 \mathrm{ng} / \mathrm{ml}$ on day 5 after oestrus, rose steadily to peak at $3.72 \pm 0.61$ and $3.64 \pm 0.58 \mathrm{ng} / \mathrm{ml}$ on days 10 and followed by a rapid decline to $0.74 \pm 0.04$ and $0.73 \pm 0.17 \mathrm{ng} / \mathrm{ml}$ on day 15 in controlled and supplemented group, respectively (Fig. 3).

\subsection{Sexual behavioral signs of estrus}

The results of investigating sexual behaviors of ewes of both groups are presented in Table 4 . All ewes showed at least one proceptive and receptive behavior in this study. The proceptive signs of estrus were soliciting, sniffing scrotum, head-turning toward ram, anogenital sniffing, squatting, tail-fanning. However, stand to be mounted was the only receptive behavior in both groups. There were no statistical differences for proceptive and receptive behaviors between controlled and supplemented group ( $p>0.05)$.The nutritional supplement did not improve sexual behaviors (Table 5).

\subsection{Pregnancy rate, Gestation length and post partum onset of estrus}

Twelve ewes were undergone for natural service in both the groups. The pregnancy rates were 83.33 and $100 \%$ in controlled and supplemented groups. The gestation length, and post partum onset of estrus in indigenous ewes is placed in Table 6. The gestation length varied from 141 to 145 days. The gestation length was significantly $(\mathrm{p}<0.01)$ lower in controlled group compared with supplemented group. The post partum onset of estrus was significantly shorter in supplemented group than controlled group $(\mathrm{P}<0.05)(28.67 \pm 7$. 24vs $42.5 \pm 5.57$ days).

\subsection{Lambing rate, Litter size and Lamb Survival rate}

The lambing rates were 75 and $100 \%$ in controlled and supplemented group, respectively (Table 6). There was no significant ( $p>0.05$ ) difference in litter size of controlled and supplemented groups $(1.22 \pm 0.44$ vs.1.58 \pm 0.67$)$. 


\subsection{Birth weight of lambs}

Birth weight and average daily gain of lambs from this study are presented in Table 6. Mean birth weights of lambs were $1.00 \pm 0.30$ and $1.33 \pm 0.25 \mathrm{~kg}$ in controlled and supplemented group, respectively. The birth weight of lambs born in supplemented groups were significantly higher $(\mathrm{p}<0.05)$ compared with lambs born in controlled group.

\subsection{Pre-weaning average daily gain and weaning weight}

The means of the pre-weaning average daily gain of indigenous sheep were significantly different $(\mathrm{p}<0.01)$ between controlled and supplemented group $(42.59 \pm 14.44 \mathrm{~g} / \mathrm{day}$ vs. $72.96 \pm 13.35 \mathrm{~g} / \mathrm{day})$. The preweaning weight gain of lambs reflected the weaning weight. The weaning weight were significantly higher $(\mathrm{p}<0.01)$ of lambs born in supplemented groups compared with controlled groups $(3.58 \pm 0.93 \& 5.71 \pm 1.03 \mathrm{~kg})$.

\section{Discussion}

The study of stress factors especially the under-nutrition interfering the breed characteristics of indigenous ewes is the basic need at the present time to increase and improve the sheep production in Bangladesh. The daily weight gain during puberty in supplemented group had better puberty parameters such as age and weight at puberty compared with controlled group. There is good evidence that in most domestic species, nutrition is an important factor for the age and body weight of puberty [21]. The energy deficiency delays puberty and decreases animal fertility, body weight gain, and other productive parameters [22]. The present data showed that the ewes in supplemented group reached puberty at significantly earlier age than ewes of traditional feeding system of farmers. The present observation is similar with the study of other researcher [23], [24, [25]. This could be due to differences in breed, nutrition and environment of study.

Plane of nutrition of ewe did not affect cycle length in ewes [26]. The average length of the estrous cycle was comparable with observations made on other breeds [27], [28]. The differences in length of the cycle between the studies could be due to phase of the breeding season age of the sheep groups and breed differences [29]. The mean duration of estrus for both groups was within the range reported in previous studies [27], [30]. However, there are some other studies in which a longer or shorter duration of estrus has been reported than that found in the present study [31], [32], [33]. This may be the possible explanation for these differences between the studies.

The predominance of vaginal epithelial cells was differing from stage to another. In studies involving the reproductive system and the influence of the estrous cycle on non-reproductive functions, vaginal smear cytology is used to determine the estrous cycle phases [34]. This method predicts the estrous cycle according to the proportion of three cells types observed in the vaginal smear: epithelial cells, cornified cells and leukocytes [18].

The average progesterone levels between days of estrous cycle for both groups were within the range reported in previous studies [32], [28], [35], [19], [36]. However, there are some other studies [37], [33] in which higher progesterone concentration have been reported between days compared with the present study. This difference could be due to differences in breed, batch of Progesterone ELISA kit and pippeting fineness.

Influence of nutrients on sexual behaviors in ewes in the present study is similar with other studies [38], [39]; [40]. Among proceptive behaviors investigated in the present study, ewes in both groups displayed head-turning and non-firm standing more frequently than soliciting, anogenital sniffing and sniffing scrotum. However, tail-fanning and squatting were not observed regularly. This result is agreed with study of Enhert and Moberg [41]. On the other hand tail wagging was the primary proceptive behavior expressed by female goats in estrus [42].

The result is self explanatory for the effects of nutrient of pregnant dam on the pregnancy rates. These findings are consistent with the observation that low energy intake reduced the pregnancy rate [43], [44], [45], [46].

Nutrition during pregnancy significantly affects the gestation length of the ewes [47]. A longer pregnancy in response to maternal under nutrition has been observed in some [47], [48], [49] but not all [50] studies and may be a response that results in increases in physiological maturity of the lamb at birth.

The basic assumption of this study was that postpartum onset of estrus of sheep is affected by nutrition. The positive effects of post-partum nutritional level of ewes on onset of oestrus have been observed by other researchers [51], [52].

A higher lambing rate may be the result of the increase in body weight gain of ewes fed the high energy diet at pre-mating and gestation. The ability of nutrition to alter the lambing rate of ewes is well known, as a rapid improvement in body weight gain is associated with an increase in ovulation rate and lambing rate [53], [54]. These findings are consistent with the observation that low energy intake reduce the lambing rate [55], [56]. There was no significant ( $p>0.05)$ difference in litter size of controlled and supplemented groups which is similar to the findings of others [44], [45], [46]. 
Lambs having light birth weight had lowest survival rates. The birth weight affect the lamb's ability to ingest colostrum and receive proper mothering shortly after birth and thus develop an ability to combat infections [57]. Improving lamb birth weight using different management interventions such as improving prepartum feeding of ewes especially animals with poor body condition carrying twins may partially solve the problem [56].

The birth weights of the lambs were affected by number of litter size. The level of nutrition during the last weeks before parturition also influenced the birth weight of lambs, [47]. The mean birth weight of indigenous lambs obtained in the current study is in agreement with literature reported by others [58], [59].

Pre-weaning growth (average daily gain) obtained in the present study is lighter than reports of [60], [58]. However, this is comparable with [61], [62].

Pre-weaning growth performance of lambs depends up on the inherent genetic potentiality and mothering ability of ewes and the environmental effects. The mean weaning weight of indigenous lambs obtained in the current study was lighter than weaning weights of other breeds [60], [63], [58], [59].

\section{Conclusion}

Our results showed that the nutritional supplement containing many nutrients improving animal health and reproduction has a positive effect on reproductive performances of indigenous ewes. These findings will be useful to help further explore the frequency and amount of multiple nutrients supplementation that may alter reproductive performance of ewes to increase and improve the sheep production in Bangladesh.

\section{Acknowledgements}

The authors wish to acknowledge Bangladesh academy of Sciences-United State Department of Agriculture (BAS-USDA) for giving the financial support of this research work.

\section{References}

[1]. Bangladesh Economic Review, Financial System Management Unit (FSMU), Finance Division, Ministry of Finance, Government of The People's Republic of Bangladesh, 2013.

[2]. M.G.S. Alam, A. Ghosh, A.K. Mondal and M.A. Akbar, Supplementation and puberty of zebu calves of Bangladesh, The Bang. Vet., 18, 2001, 1-8.

[3]. M.H. Rahman Dairy Development and Meat production, National Livestock Policy Document: FAO, Dhaka, Bangladesh, 2005.

[4]. M.G.S. Alam, M.S. Azam and M.J. Khan, Supplementation with urea and molasses and body weight, milk yield and onset of ovarian cyclicity in cows, J Reprod. Dev., 52, 2006, 529-535.

[5]. E. Mukasa-Mugerwa, D. Anindo, S. Sovani, A. Lahlou-Kassi, S. Tebely, J.E.O. Rege and R.L. Baker, Reproductive performance and productivity of Menz and Horro sheep lambing in the wet and dry seasons in the highlands of Ethiopia, Small Rumin. Res., 45, 2002, 261-271.

[6]. L. Getahun, Productive and Economic performance of Small Ruminant production in production system of the Highlands of Ethiopia, Ph.D. dissertation. University of Hohenheim, Stuttgart-Hoheinheim, Germany, 2008.

[7]. M.P. Boland, P. Lonergan and O. Callaghan, Effect of nutrition on endocrine parameters, ovarian physiology, and oocyte and embryo development, Theriogenology, 55, 2001) 1323-1340.

[8]. A.V. Capuco, D.L. Wood, S.A. Bright, R.H. Miller and J. Britman, Regeneration of teat canal keratin in lactating dairy cows, J. Dairy sci., 73, 1990, 1051-1057.

[9]. B.W. Hess, S.L. Lake, E.J. Scholljegerdes, T.R. Weston, V. Nayigihugu, J.D.C. Molle and G.E. Moss, Nutritional controls of beef cow reproduction, J. Anim. Sci. 83(E-Suppl.), 2005, E90-E106.

[10]. R.P. Wettemann, C.A. Lents, N.H. Ciccioli, F.J. White and I. Rubio Nutritional- and suckling-mediated anovulation in beef cows, J. Anim. Sci. 81(E-Suppl. 2), 2003, E48-E59.

[11]. K.M. Godfrey and D.J. Barker, Fetal nutrition and adult disease, Am. J. Clin. Nutr., 71(Suppl.), 2000, 1344S-1352S.

[12]. G. Wu, F.W. Bazer, J.M. Wallace and T.E. Spencer, Intrauterine growth retardation: Implications for the animal sciences, J. Anim. Sci., 84, 2006, 2316-2337.

[13]. S.W. Kochapakdee, S. Pralokarn, A.S. Laapetchara and B.W. Norton, Grazing management studies with Thai goats. Productivity of female goats grazing newly established pasture with varying levels of supplementary feeding, Asian- Aust. J. Anim. Sci., 7, 1994, 289-293.

[14]. J.M. Mahajan, D.S. Chauhan and V.P.S. Tomar, Effect of supplementary feeding to grazing on growth and wool production in sheep, Indian J. Anim. Res., 10 ,1976, 90-92.

[15]. R.D. Smith and L.E. Chase, Nutrition and Reproduction, Dairy Integrated Reproductive Management , 2010.

[16]. AOAC: Official Methods of Analysis BY ORDER OF THE EXECUTIVE DIRECTOR, Office of the Federal Register, Washington, D.C. By Authority of the Code of Federal Regulations: 21 CFR 131.150(c), 1980.

[17]. P. Chemineau, A. Daveau, F. Maurice and J.A. Delgadillo, Seasonality of estrus and ovulation is not modified by subjecting female Alpine goats to a tropical photoperiod, Small Rumin. Res., 8, 1992a, 299-312.

[18]. F.K. Marcondes, F.J. Bianchi and A.P. Tanno, Determination of the estrous cycle phases of rats: some helpful considerations, Braz J Biol,. 62, 2002, 609-614.

[19]. A. Perkins and J.A. Fitzgerald, The behavioral component of the ram effect: The influence of ram sexual behavior on the induction of estrus in anovulatory ewes, J. Anim. Sci., 72, 1994, 51-55.

[20]. E. Landais and M.M. Cissoko, Methodological bases for measuring animal performances, IEMVT/ISRA, 1986, 433-485.

[21]. L.E. McDonald, Veterinary endocrinology and reproduction, Lea and Febiger, Philadelphia, USA., 1980,560 pp.

[22]. H. Fernando, E. Laura, G. Juan-Vicente and G.S. Antonio, Influence of age at first lambing on reproductive and productive performance of Lacaune dairy sheep under an intensivemanagement system , J. Dairy Res., 78, 2011, $160-167$.

[23]. E.I. Khalifa, M.E. Ahmed, Y.H. Hafez, O.A. El-Zolaky, K.M. Bahera and A.A. Abido, Age at puberty and fertility of Rahmani sheep fed on biological inoculated corn silage, Ann. Agric., Sci., 58, 2013, 163-172. 
[24]. R. Ionel, G. Lucica, M. Viorel, R. Flavia, R. Vasile and P. Raul, The onset of puberty in hybrid merino ewe lambs born in autumn, in the lower Danube area, Bull. UASMV, Vet. Med., 69, 2012, 171- 173.

[25]. P.M. Bartlewski, A.P. Beard and S.J.e.a. Cook, Ovarian activity during sexual maturation and following introduction of the ram to ewe lambs, Small Rumin. Res., 43, 2002, 37-44.

[26]. P. Kassem, J.B. Owen and I. Fadel, The effect of premating nutrition and exposure to the presence of rams on the onset of puberty in Awassi ewe lambs under semi-arid conditions, Anim. Prod., 48, 1989, 393-398.

[27]. A.Q. Talafha and M.M. Ababneh, Review Awassi sheep reproduction and milk production, Trop. Anim. Health Prod., 43, 2011, 1319-1326.

[28]. S.M.K. Naqvi, A. Joshi, G.K. Das and J.P. Mittal, Development and application of ovine reproductive technologies: an Indian experience, Small Rumin. Res., 39, 2001, 199-208.

[29]. J.P. Ravindra and N.C. Rawlings, Ovarian follicular dynamics in ewes during the transition from anoestrus to the breeding season, J. Reprod. Fertil., 110, 1997, 279-289.

[30]. E. Elias, D. Cohen and P. Dayenoff, Characteristics and indices of reproduction in Dorper sheep, J. S. Afr. Vet. Assoc, 56, 1985, $127-130$.

[31]. J. Menegatos, S. Chadio, T. Kalogiannis, T. Kouskoura and S. Kouimtzis, Endocrine events during the periestrous period and the subsequent estrous cycle in ewes after estrus synchronization, Theriogenology, 59, 2003, 1533-1543.

[32]. D.M.W. Barret, P.M. Bartlewski, S.J. Cook and N.C. Rawlings, Ultrasound and endocrine evaluation of the ovarian response to PGF2 $\alpha$ given at different stages of the luteal phase in ewes, Theriogenology, 58, 2002, 1409-1424.

[33]. R.W. Godfrey, J.R. Collins and E.L. Hensley, Behavioral and endocrine responses of hair sheep ewes exposed to different mating stimuli around estrus, Theriogenology, 55, 2001, 877-884.

[34]. T. Yener, Turkkani, A. Tunc, H. Aslan, H. Aytan and A. Cantug Caliskan Determination of oestrous cycle of the rats by direct examination: how reliable? Anat Histol Embryol., 36, 2007, 75-77.

[35]. P.M. Bartlewski, A.P. Beard and N.C. Rawlings, The relationship between vaginal mucous impedance and serum concentrations of estradiol and progesterone throughout the sheep estrous cycle, Theriogenology , 51, 1999, 813-827.

[36]. E. Mukasa-Mugerwa, Zere Ezaz and P. Viviani, Plasma concentrations of progesterone during oestrous cycles of Ethiopian Menz sheep using enzyme immunoassay, Small Rumin. Res., 3, 1990, 57-62.

[37]. R. Ungerfeld and E. Rubianes, Estrus response to the ram effect in Corriedale ewes primed with medroxyprogesterone during the breeding season, Small Rumin. Res., 32, 1999, 89-91.

[38]. F. KARAAĞAÇ, M. ÖZCAN and T. SAVAŞ, Some behaviour traits observed on the Kıvırctk and Crossbred lambs raised in intensive conditions, Turk. J. Vet. Anim. Sci., 29, 2005, 803-809.

[39]. G. Kutsarov, Y. Iliev, I. Varliakov, I. Penchev Georgiev and V. Radev, Effect of hypokinesia on the behaviour of lambs, Bulg.J. Vet. Med., 7, 2004, 69-75.

[40]. H. Gelez, E. Archer, D. Chesneau, D. Lindsay and C. Fabre-nys, Role of experience in the neuroendocrine control of ewes' sexual behavior, Horm. Behav., 45, 2004, 190-200.

[41]. K. Enhert and G.P. Moberg, Disruption of estrous behavior in ewes by dexamethasone or management-related stress, J. Anim. Sci., 69, 1991, 2988-2994.

[42]. D. Bradley Imwalle and L.S. Kartz, Divergent roles for estrogens and androgens in the expression of female goat sexual behavior, Horm.Behav., 46, 2004, 54-58.

[43]. N.T. Kusina, T. Chinuwo, H. Hamudikuwanda, L.R. Ndlovu and S. Muzanenhamo, Effect of different dietary energy level intakes on efficiency of estrus synchronization fertility in Mashona goat does, Small Rumin. Res., 39, 2001, 283-288.

[44]. F.M. El-Hag, M.-K.A. Ahmed, A.M. Salih and K.M.A. Mohamed, Supplementary feeding to improve Desert sheep productivity under dryland farming, Tropical Sci., 47, 2007, 26-32.

[45]. A. El-Toum, Effect of pre-partum supplementary feeding on desert ewe productivity under rangelands in north Kordofan, Sudan. M.Sc. Thesis (Animal production) University of Khartoum, Sudan, 2005.

[46]. Bukhari, The Effect of Supplementation of Low Quality Roughage with Concentrates on Dry Matter Intake and Performance of Desert Sheep Lambs, Sudan, M.Sc. Thesis (Faculty of Natural Resources and Environmental Studies) University of Kordofan, 2005.

[47]. P.K. Holst, ID; Cullis, BR Nutrition of the pregnant ewe and its effect on gestation length, lamb birth weight and lamb survival, 1986.

[48]. J.M. Wallace, J.S. Milne and R.P. Aitken,The effect of overnourishing singleton-bearing adult ewes on nutrient partitioning to the gravid uterus, Br. J. Nutr., 94, 2005, 533-539.

[49]. C. Munoz, A.F. Carson, M.A. McCoy, L.E.R. Dawson, N.E. O’Connell and G.A. W. , Nutritional status of adult ewes during early and mid-pregnancy. 1. Effects of plane of nutrition on ewe reproduction and offspring performance to weaning, Animal, 2, 2008, $52-63$.

[50]. C. Munoz, A.F. Carson, M.A. McCoy, L.E.R. Dawson, N.E. O'Connell and A.W. Gordon, Effect of plane of nutrition of 1- and 2year-old ewes in early and mid-pregnancy on ewe reproduction and offspring performance up to weaning, Animal, 3, 2009, 657669.

[51]. L.A. Zarazaga, J.L. Guzman, C. Dominguez, M.C. Perez and R. Prieto, Effect of plane of nutrition on seasonality of reproduction in Spanish Payoya goats, Anim. Reprod. Sci,. 87, 2004, 253-267.

[52]. S.G. Haddad, R.T. Kridli and D.M. Al-Wadi Influence of varying levels of dietary undergraded intake protein on nutrient intake, body weight change, and reproductive parameters in postpartum Awassi ewes, Asian-Australas. J. Anim. Sci., 18, 2005, 637-642.

[53]. S.M. Rhind and A.S. Mc Neilly, Effects of level of feed intake on ovarian follicle number size and steroidogenic capacity in the ewe, Anim. Reprod. Sci., 52, 1998, 131-138.

[54]. M.B. Nottle, D.O. Kleemann and R.F. Seamark, Effect of previous undernutrition on the ovulation rate of Merino ewes supplemented with lupin grain, Anim. Reprod. Sci., 49, 1997, 29-36.

[55]. E. Mukasa-Mugerwa, A. Lahlou-Kassi, D. Anindo, J.E. Rege, S. Tembely, M. Tibbo and R.L. Baker, Between and within breed variation in lamb survival and the risk factors associated with major causes of mortality in indigenous Horro and Menz sheep in Ethiopia, Small Rumin. Res., 37, 2000, 1-12.

[56]. D. Gemeda, S.J. Schoeman, S.W.P. Cloete and G.F. Jordaan, The effect of non-genetic factors on pre-weaning survival rate in the Tygerhoek Merino lambs, Eth. J. Anim. Prod., 2002, 115-125.

[57]. A. Mandal, H. Prasad, A. Kumar, R. Roy and N. Sharma, Factors associated with lamb mortalities in Muzaffarnagari sheep, Small Rumin. Res., 71, 2007, 273-279. 
[58]. Mengistie Taye, Girma Abebe, Solomon Gizaw, Sisay Lemma, Abebe Mekoya and M. Tibbo, Growth performances of Washera sheep under smallholder management systems in Yilmanadensa and Quarit districts, Ethiopia, Trop. Anim. Health Prod. , DOI 10.1007/s11250-009-9473-x, 2010.

[59]. S. Abegaz, B.P. Hegde and M. Taye, Growth and Physical Body Characteristics of Gumuz Sheep under Traditional Management Systems in Amhara Regional State, Ethiopia, Livestock Research for Rural Development, 2011, 23, Article \#117.

[60]. K. Awgichew, Comparative performance evaluation of Horro and Menz sheep of Ethiopia under grazing and intensive feeding conditions, Ph.D. Dissertation at eingereicht an der Landwirtschaftlich-Gärtnerischen Fakultät der Humboldt-Universität zu Berlin, 2000, 6-22.

[61]. G. Berhane and L.O. Eilk, Effect of Vetch (Vicia sativa) hay supplementation to Begait and Abergelle goats in northern Ethiopia II. Reproduction and growth rate, Small Rumin. Res., 64, 2006, 233-240.

[62]. W. Tatek, Hailu Dadi, Mieso Guru and D. Gelashe, Productivity of Arsi Bale goat types under farmers' management condition: a case of Arsi Negelle. In: Tamrat Degefa and Fekede Feyissa (eds), Proceedings of the 13th Annual Conference of the Ethiopian Society of Animal Production (ESAP) held in Addis Ababa, Ethiopia, August 25-27, 2004. ESAP, Addis Ababa (2004) pp67-71.

[63]. M. Tibbo, Productivity and health of indigenous sheep breeds and crossbreds in the central Ethiopian highlands, Ph.D. dissertation. Department of Animal Breeding and Genetics, Faculty for Veterinary Medicine and Animal Sciences, Swedish University of Agricultural Sciences (SLU), Uppsala, Sweden, 2006, 76p.

Table1: Results of proximate composition analysis of ingredients (\% moisture basis)

\begin{tabular}{|l|c|c|c|c|c|c|}
\hline \multirow{2}{*}{ Nutrients } & \multicolumn{7}{|c|}{ Chemical composition (\%) } \\
\cline { 2 - 7 } & Crude Protein & Crude fiber & Ash & Lipid & Carbohydrate & Moisture \\
\hline Crushed Maize & 18.35 & 5.70 & 12.84 & 9.85 & 41.06 & 12.20 \\
\hline Wheat Bran & 15.55 & 6.20 & 16.36 & 9.65 & 40.93 & 11.31 \\
\hline Soyabean meal & 28.78 & 5.6 & 13.34 & 8.85 & 33.47 & 10.36 \\
\hline Fish meal & 58.25 & 0.35 & 16.54 & 10.24 & 2.02 & 12.56 \\
\hline
\end{tabular}

Table 2: Reproductive performances of indigenous ewes (Mean \pm SD)

\begin{tabular}{|l|c|c|}
\hline \multicolumn{1}{|c|}{ Parameters } & $\begin{array}{c}\text { Controlled group } \\
(\mathbf{N = 1 2})\end{array}$ & $\begin{array}{c}\text { Supplemented group } \\
(\mathbf{N}=12)\end{array}$ \\
\hline Age at puberty(months) & $8.43 \pm 1.15^{\mathrm{a}}$ & $6.22 \pm 1.31^{\mathrm{b}}$ \\
\hline Weight at Puberty(kg) & $9.16 \pm 1.06^{\mathrm{a}}$ & $10.38 \pm 0.39^{\mathrm{b}}$ \\
\hline Average daily gain(g/day/ewe) & $21.19 \pm 4.71^{\mathrm{b}}$ & $40.95 \pm 12.07^{\mathrm{a}}$ \\
\hline Estrus cycle length(days) & $16.06 \pm 0.35^{\mathrm{ns}}$ & $15.81 \pm 0.38^{\mathrm{ns}}$ \\
\hline Duration of estrus (hrs.) & $32.75 \pm 3.19^{\mathrm{ns}}$ & $33.17 \pm 3.01^{\mathrm{ns}}$ \\
\hline
\end{tabular}

${ }^{\mathrm{a}-\mathrm{b}}$ Values with different superscripts in the same rows are significantly different $(\mathrm{P}<0.01)$. ns: $\mathrm{p}>0.05$

Table 3: Serum progesterone concentration $(\mathrm{ng} / \mathrm{ml})$ in different days of the estrous cycle in indigenous ewes (Mean $\pm \mathrm{SD}$ )

\begin{tabular}{|l|c|c|}
\hline \multirow{2}{*}{ Days of Estrus cycle } & \multicolumn{2}{|c|}{$\begin{array}{c}\text { Progesterone concentration } \\
\text { (ng/ml) }\end{array}$} \\
\cline { 2 - 3 } & Controlled group $^{\text {Supplemented group }}$ \\
\hline 0 (Estrus) & $0.11 \pm 0.04^{\mathrm{d}}$ & $0.12 \pm 0.07^{\mathrm{d}}$ \\
\hline 5 & $1.48 \pm 0.25^{\mathrm{b}}$ & $1.59 \pm 0.33^{\mathrm{b}}$ \\
\hline 10 & $3.72 \pm 0.61^{\mathrm{a}}$ & $3.64 \pm 0.58^{\mathrm{a}}$ \\
\hline 15 & $0.74 \pm 0.04^{\mathrm{c}}$ & $0.73 \pm 0.17^{\mathrm{c}}$ \\
\hline
\end{tabular}

${ }^{a-d}$ Values with different superscripts in the same column are significantly different $(p<0.01)$.

Table 4: Sexual behavioral signs recorded during the observation periods

\begin{tabular}{|c|c|}
\hline \multicolumn{2}{|c|}{ Proceptive behavior } \\
\hline Soliciting & $\begin{array}{l}\text { The ewe approaches to the ram, nuzzles the body of him, shows a } \\
\text { tendency to stay in the vicinity of the ram and follows him }\end{array}$ \\
\hline Head lifting & The ewe lifts head upon the body of the ram \\
\hline Sniffing scrotum & The ewe sniffs the scrotum and anogenital region of the ram \\
\hline Head-turning & The ewe stands and swings her head to look at the courting ram \\
\hline Anogenital sniffing & The ewe allows the ram to sniff her tail and genitalia \\
\hline Non-firm standing & $\begin{array}{l}\text { The ewe stands in front of the ram in response to the courtship of } \\
\text { him but does not allow him to mount and she avoids when the } \\
\text { ram attempts to mount }\end{array}$ \\
\hline Squatting & Typical urination posture of the ewe \\
\hline Tail-fanning & Repeated movement of the tail \\
\hline \multicolumn{2}{|l|}{ Receptive behavior } \\
\hline Firm standing & The ewe stands still to receive a mount attempt or mount \\
\hline
\end{tabular}


Table 5: The percentage of expressed proceptive and receptive behaviors in indigenous ewes of Controlled and Supplemented group

\begin{tabular}{|c|c|c|}
\hline Sexual Behavioral Signs & $\begin{array}{c}\text { Controlled Group } \\
(\mathbf{n = 1 2})\end{array}$ & $\begin{array}{c}\text { Supplemented Group } \\
(\mathbf{n = 1 2})\end{array}$ \\
\hline Proceptive & $44.4^{\text {ns }}$ & $55.6^{\text {ns }}$ \\
\hline Receptive & $47.8^{\text {ns }}$ & $52.2^{\text {ns }}$ \\
\hline Total & $45.5^{\text {ns }}$ & $54.5^{\text {ns }}$ \\
\hline
\end{tabular}

ns: not significant $(\mathrm{P}>0.05)$

Table 6: Reproductive performances of indigenous ewes (Mean \pm SD)

\begin{tabular}{|l|c|c|}
\hline \multicolumn{1}{|c|}{ Parameters } & $\begin{array}{c}\text { Controlled group } \\
(\mathbf{N = 1 2})\end{array}$ & $\begin{array}{c}\text { Supplemented group } \\
(\mathbf{N}=12)\end{array}$ \\
\hline Gestation length(days) & $141.80 \pm 1.23^{\mathrm{b}^{*}}$ & $144.50 \pm 1.17^{\mathrm{a}^{*}}$ \\
\hline Post partum onset of estrus(days) & $42.5 \pm 5.57^{\mathrm{a}^{*}}$ & $28.67 \pm 7.24^{\mathrm{b}^{*}}$ \\
\hline Pregnancy rate\% & $10(83.33)$ & $12(100)$ \\
\hline Lambing rate\% & $9(75)$ & $12(100)$ \\
\hline Litter size & $1.22 \pm 0.44^{\mathrm{ns}}$ & $1.58 \pm 0.67^{\mathrm{ns}}$ \\
\hline Lamb survival rate (\%) & $91.67 \%$ & $1.33 \pm 0.25^{\mathrm{a}^{* *}}$ \\
\hline Lamb birth weight (kg) & $1.00 \pm 0.30^{\mathrm{b}^{* *}}$ & $5.71 \pm 1.03^{\mathrm{a}^{*}}$ \\
\hline Weaning weight(kg) & $3.58 \pm 0.93^{\mathrm{b}^{*}}$ & $72.96 \pm 13.35^{\mathrm{a}^{*}}$ \\
\hline Pre-weaning average daily weight gain (g/day/lamb) & $42.59 \pm 14.44^{\mathrm{b}^{*}}$ & \\
\hline
\end{tabular}

${ }^{\mathrm{a}-\mathrm{b}}$ Values with different superscripts in the same rows are significantly different. $* \mathrm{p}<0.01, \quad * * \mathrm{p}<0.05, \quad \mathrm{~ns}: \mathrm{p}>0.05$

\begin{tabular}{|c|c|c|c|c|} 
Day -1,-2 & Day 0 & Day 1to 3/4/5 & Day 4/5 to 13/14/15 & Day 16/17 \\
\hline PE & E & ME & DE & PE \\
\hline
\end{tabular}

\begin{tabular}{lllll}
\hline Vaginal smear N(C) & C & L(NC) & L(NC) & N(C)
\end{tabular}

Fig. 1 The upper panel shows the 16/17 day ewe oestrus cycle, where PE= Proestrus; E= Estrus; ME= Metestrus and $\mathrm{DE}=$ Diestrus. The lower panel shows the vaginal smear during different stages of oestrus cycle. $\mathrm{N}=$ Nucleated epithelial cells; $\mathrm{L}=$ Leukocytes and $\mathrm{C}=$ Cornified cells
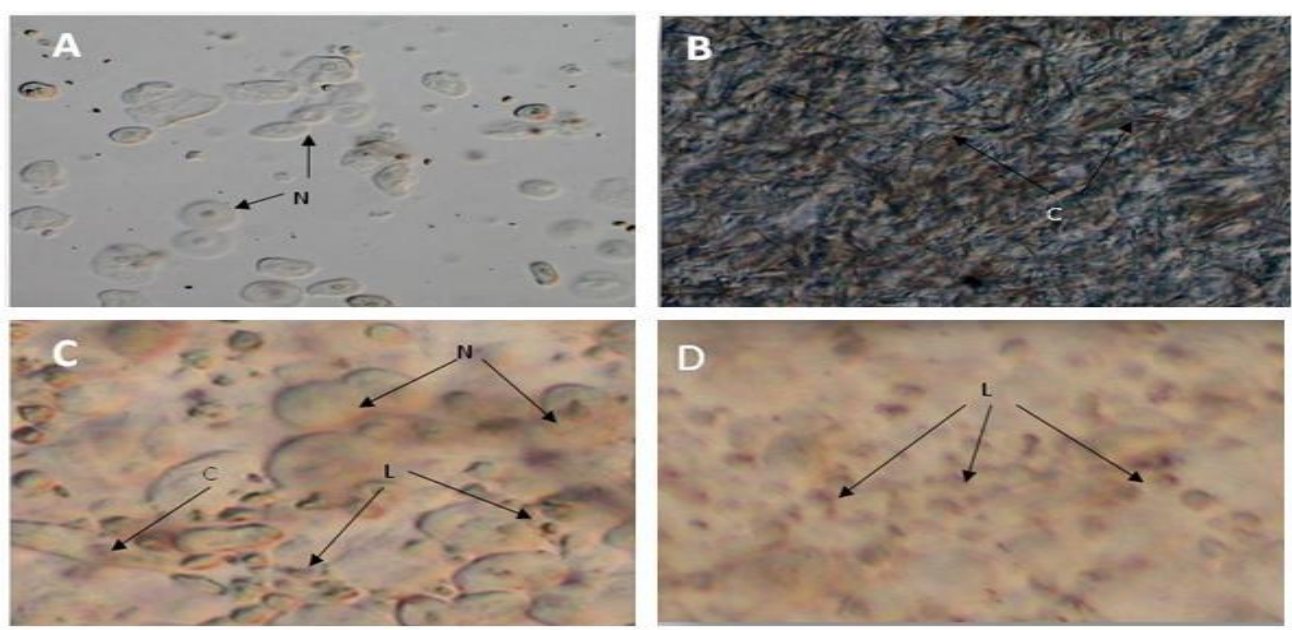

Fig.2. Photomicrographs of unsta ined vaginal smear from indigenous ewes at (A) proestrus, predominantly consisting of nucleated ep ithelial ce11s; (B) oestrus, with anucleated cornified cells; (C) metestrus, consisting of the three types of ce11, leukocytes, cornified and nucleated ep ithelial cells and (D) dioestrus, consisting predominatly of leukacytes. Nucleated ep ithelial cells (N), leukocytes (I), and comified cells (C). 


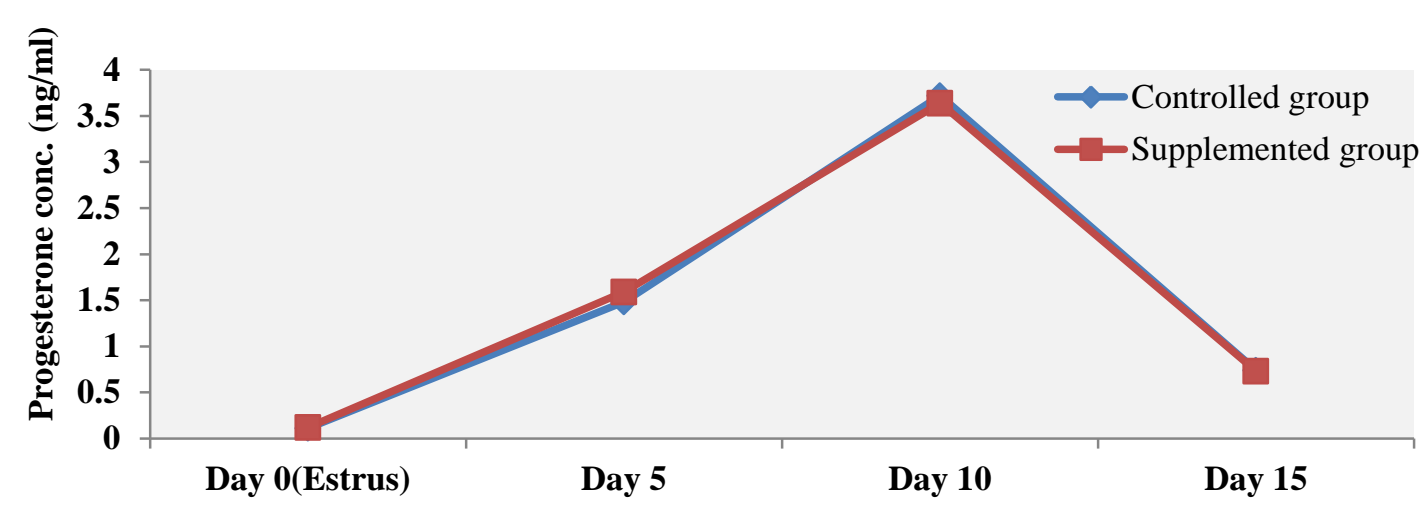

Days of Estrus cycle

Fig. 3 Progesterone concentrations in Indigenous ewes of controlled and supplemented group 